IRA-International Journal of Management \& Social Sciences

ISSN 2455-2267; Vol.10, Issue 01 (January 2018)

Pg. no. 46-53.

Institute of Research Advances

http://research-advances.org/index.php/RAJMSS

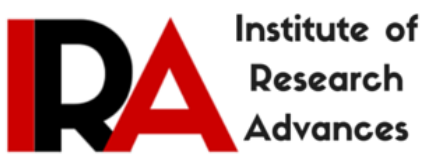

\title{
A Study on the Problems of Elected Women Gram Panchayat Members before Contesting Election in Dakshina Kannada District, India
}

\author{
Ravishankar K.R. \\ Research Scholar, School of Social Work, Roshni Nilaya, Mangalore, Affiliated to Mangalore University, \\ Dakshina Kannada District, Karnataka State, India. \\ $\&$ \\ Assistant Professor, MSW Department, P.G.Centre SDM College, Ujire, Belthangady, Karnataka State, \\ India.
}

Type of Review: Peer Reviewed.

DOI: http://dx.doi.org/10.21013/jmss.v10.n1.p5

How to cite this paper:

Ravishankar, K.R. (2018). A Study on the Problems of Elected Women Gram Panchayat Members before Contesting Election in Dakshina Kannada District, India. IRA-International Journal of Management \& Social Sciences (ISSN 2455-2267), 10(1), 46-53. doi:http://dx.doi.org/10.21013/jmss.v10.n1.p5

(C) Institute of Research Advances.

(c)) BY-NC

This work is licensed under a Creative Commons Attribution-Non Commercial 4.0 International License subject to proper citation to the publication source of the work.

Disclaimer: The scholarly papers as reviewed and published by the Institute of Research Advances (IRA) are the views and opinions of their respective authors and are not the views or opinions of the IRA. The IRA disclaims of any harm or loss caused due to the published content to any party.

Institute of Research Advances is an institutional publisher member of Publishers Inter Linking Association Inc. (PILA-CrossRef), USA. The institute is an institutional signatory to the Budapest Open Access Initiative, Hungary advocating the open access of scientific and scholarly knowledge. The Institute is a registered content provider under Open Access Initiative Protocol for Metadata Harvesting (OAI-PMH).

The journal is indexed \& included in WorldCat Discovery Service (USA), CrossRef Metadata Search (USA), WorldCat (USA), OCLC (USA), Open J-Gate (India), EZB (Germany) Scilit (Switzerland), Airiti (China), Bielefeld Academic Search Engine (BASE) of Bielefeld University, Germany, PKP Index of Simon Fraser University, Canada. 


\begin{abstract}
Women representation in Gram Panchayat plays very important role in contemporary Society.Reseration is one of the legislative efforts to empower women especially for the political participation. This article mainly dealt with the problems faced by elected women Gram Panchayat members before contesting Gram Panchayat election. The youngsters were participating in politics and majority of them were also educated .The family head and also political parties were preparing women to contest in the Gram Panchayat elections. Interestingly few respondents were also spent their own money to contest in the Gram Panchayat election.. Some respondents were actively participating in Gram Panchayat activities. But before the elections even if they are not interested to contest election also, either they were forced or prepared to contest in the election.
\end{abstract}

Key words - Women, Panchayat, Gram Panchayat, Election, politics

\title{
1. Introduction
}

If we want to feel the taste of democracy, villages should be democratized. Each citizen of the village should feel that he/ she is enjoying freedom and fulfilling their needs satisfactorily.

Gandhi said (New Delhi 06-01-1948) "In the true democracy of India, the unit was the village. Even if one village wanted Panchayat raj which was called republic in English, no one could stop it. True democracy could not be worked by 20 members sitting at the center. It had to be moved from below by the people of every village"

Spirit of the people of India lives in villages of the country. Our democracy cannot become strong unless the democracy of the village is strong. Now it is realized that genuine development of rural areas can take place only through a process of decentralized planning, implementation and fully involving the local people. To achieve this goal, one should stand committed to the task of devolution of powers and financial resources to the Panchayati Raj Institutions enabling fullest participation of people in the process of nation building activities and development.

The role of men and women in the development process has received much attention in last few decades concerns with regard to women and their inclusion or exclusion in the development process have been increasingly examined. Although the principle of equality of men and women were recognized as early as 1945 in the UN charter and in the UN declaration of human rights of 1948.In independent India after $73^{\text {rd }}$ amendment (1992) tremendous changes have been made in grass root level administration. Reservation to women is one of the key issue in this amendment. It is a revolutionary decision, good beginning and welcome step, having revolutionary implication.

In August 2009, the Union cabinet presided over by then Prime Minister Dr.Manmohan Singh, cleared a proposal to amend article 243(D) of the constitution thus rising reservation for women in all hires of the Panchayat raj system from the existing 33\% to atleast50\%. However in most of the states as in Karnataka, where women have been theoretically 'empowered' through 50\% reservation of seats in Panchayat raj institutions, there has been not let up in resentment skepticism over their abilities and genuine powerlessness.

Women constitute nearly $50 \%$ of the population of the world. But when it comes to their representation at higher levels of political position in the government, they account for only less than $10 \%$. The gender inequality, which is of concern to the issue of human development the world over, is also manifested in many other forms. For instance women still constitute $70 \%$ of the world's poor and two third of the world's illiterates. They often work longer hours as compared to men, but much of their work remains unvalued, undervalued and unrecognized.

Factors that restrain participation are also both psychological and demographic. Psychological factors that inhibit participation are compliance with social restriction, shyness and submissiveness, lack of understanding of their role and responsibilities and weak articulation, interaction and influential skills among others. Demographic factors that inhibit participation are illiteracy, low level of education, religion and caste.

The directive principles of state policy enshrined in the part fourth of the Indian Constitution has a special bearing the status and empowerment of women. The Indian Constitutions guarantees political equality to women through the provision of adult franchise. This reorganization was certainly a radical departure from socio cultural norms of traditional Indian society. Grass root administration and good governance could not have been possible 
without the participation and empowerment of women. The low self-esteem and lack of confidence among women combined with their negative stereotypes as illiterate and lack of hopes termed to restrict their participation in Panchayati raj institutions.

Majority of the Indian rural woman are engaged in domestic work. Some of them are also engage in other activities like collection of food, fodder and fuel collections etc. They still not so comfortable to participate in politics ( Ghosh 2002).

\section{Review of Literature}

The purpose of a review is to analyze critically a segment of a published body of knowledge through summary, classification, and comparison of prior research studies, reviews of literature, and theoretical articles. The review of literature is helpful to the researcher to critically analyze the issues pertaining to research topic.

Singh Sisodia Yatindra, in his book, Functioning of Panchayat Raj System, mainly focused on empowering women through Panchayat Raj Institutions in Gujarat: some field experiences written by Chaya Patel and Women in Panchayat in Madhya Pradesh by Deepika Gupta. The central concern of Social Work discipline and profession has been to pay attention to improve the conditions of the neediest and marginal sections of the society. The objective of changing power relations in all areas of life is an extremely difficult task, especially in developing societies like India. This is an optimistic situation as the women empowerment has a prospect to raise in future from their involvement and participation in Panchayat Raj Institutions. This experience raises our hope that the processes of women empowerment are on slow and gradual, but it is in proper direction.

Joshi Meenakshi, Joshi Manisha and Pandey Jaya, in their book Women participation in Panchayat Raj: (Experience from Uttarakhand), clearly mentioned about the results, attitude of the community towards reservation of seats for the women, decision making ability of women members and service delivery by women members, fighting against corruption, relation between men and women and elected representatives. Here, community people's response is not much satisfactory. In most of the cases, training support is provided to the women Panchayat members. The mind set of women members and also society, has been changed a lot but at the same time, little more changes are required.

B.Dharmalingam and K.Dastagir Gulam in their article, emerging women leadership and Rural local Government inclusive legislation in Tami Nadu: Social Welfare magazine, said about role of women leaders in rural local Government, strategies for gender mainstreaming in rural local Government and awareness creation for the better participation. The importance issue through women's reservation is gender mainstreaming.

Nagashetty Mallikarjun and Reddy Somanath in their article, Political Empowerment of woman through Panchayat Raj Institutions, Southern Economist given importance to women empowerment, mainly in connection with political decision making. Illiteracy and traditionalism are major demerits in social settings. Panchayat Raj Institution has brought rural women to the form, who are showing enough maturity to closely align themselves with the political power structure, however, women's participation is not entirely visible and effective as their potential remains largely unrecognized and their contributions are often undermined.

M. Samad Abdul in his article, Women Empowerment and Panchayati Raj Institutions in Kerala, Kurukshetra, said that family is willing to rise to the occasion and free from her household burden and need to facilitate her to take up the new assignment. This is a remarkable deviation from traditional outlook of our society, says the study in Kerala.

Sinha, A. K, in his article Panchayati Raj and Empowerment of Women, discussed about Panchayati Raj was in existence during the Vedic period in ancient India and worked well as the people carried out their personal and official duties based on dharma. After Independence, the Government of India, under the influence of Mahatma Gandhi, was committed to set up Panchayati Raj system to provide real swaraj to the people of rural areas.

Jagrani Devi (2003), had interview with Panchayat members, brought some issues. A common picture is that of women representatives functioning as proxy candidates under the close observation and supervision of their 
'guardians'. The use of phrases such as 'pati pradhans' is common place. At the same time there are many women representatives and pradhans who have taken bold initiatives. They have not only set an example for male dominated society but also demonstrate that changes are taking place, albeit slowly. Jagrani Devi belongs to a SC family. At present she is gram pradhan of Hamirpur gram panchayat in Kasmanda development block of Sitapur district in U.P. She was elected as gram pradhan for the first time in the year 2000, and has subsequently taken several initiatives for development in the panchayat. This interview with Jagrani Devi was conducted by team members of the Sahbhagi Shikshan Kendra (SSK) - a state level NGO working to strengthen panchayati raj in U.P.

\section{Methodology}

Thus, the present study has made an attempt to identify with the opinion of elected women representatives of Gram Panchayat in Dakshina Kannada district. For any research venture, it is essential to have a sound methodology. This gives a accurate framework to carry out research systematically. This chapter discusses the research methodologically followed in the study. It is also a outline of the entire research process.

The research strongly focused on Dakshina Kannada District of Karnataka state in India.

\subsection{Scope of the study}

The scope of the study is only limited to understand the various problems faced by elected women Gram Panchayat members before Panchayat election. So the result of the study cannot be universalized to the problems faced by elected male panchayat members and also elected female member of other places of Karnataka.

\subsection{Objective of the Study:}

To know about the issues and prospectus of elected women Gram Panchayat members before contesting election.

\subsection{Research Design}

The present study is based on descriptive research design. The research was carried out among elected women Gram Panchayat members. It has attempted to describe the problems faced by elected women members of Gram Panchayats before elections

\subsection{Universe and Sampling of the study}

The geographical universe of the study comprises of elected female members of Gram Panchayat in Dakshina Kannanda District.Total elected women members are 1787 in five taluks.

Multistage sampling techniques adopted where in the first stage, Taluks were considered as strata and in each taluks all the Panchayats were listed and Panchayats were selected from each strata in selected Panchayats. 5 Members were included for the study, so that total sample size was 330 .

\subsection{Tools of Data collection}

In order to fulfill the objective of the study, the following tools were developed to gather primary data from various respondents with regard to elected female Gram Panchayat members. Questionnaires covered demographic background of the elected women Gram Panchayat members and problems faced before Gram Panchayat elections

\subsection{Methods of data collection}

The primary data was collected through questionnaires.

\subsection{Secondary data}

The researcher also gathered data from secondary sources with regard to problems of elected women Gram Panchayat members. The secondary data collected from annual reports, national and international journals, books newspapers, dissertations, articles and from the internet web pages. 


\section{Results and Discussion of the study}

Table no 1. Age of the Respondents:

\begin{tabular}{|c|c|c|c|}
\hline & & & \\
Sl.No & Age & No. of respondents & Percentage \\
\hline 1 & $18-27$ years & 12 & 3.6 \\
\hline 2 & $28-37$ years & 113 & 34.2 \\
\hline 3 & $38-47$ years & 142 & 43.0 \\
\hline 4 & $48-57$ years & 51 & 15.5 \\
\hline 5 & 58 or more & 12 & 3.6 \\
\hline & Total & $\mathbf{3 3 0}$ & $\mathbf{1 0 0}$ \\
\hline
\end{tabular}

Table Number 1 highlights that the age group of respondents. It shows that $12(3.6 \%)$ respondents were belong to 18 to 27 age group. 113(34.2\%) respondents were belong to 28 to 37 age group, 142(43.0\%) respondents were belongs to 38 to 47 age group, 51(15.5\%) respondents were belong to 48 to 57 age group and 12(03.6\%) respondents were belong to 58 and above age.

It is understood that $255(77.2 \%)$ respondents belong to 27 to 47 age group. It shows that young and middle aged respondents were contesting for election. It is also interesting to see that $12(3.6 \%)$ respondents were belongs to 18 to 27 age group. Out of 330 respondents 63 (19.1\%) of respondents were belongs to 48 and above age group. Recently more and more youths were also contesting for the election even in grass root level local self government. It is also one of the good sign and especially among women it has been developed either may be because of reservation or may be personal interest. It helps them to develop their personality and beneficial to the Community.

Study report sponsored by government of India in the year 2008 on 'empowerment of women through participation in panchayati raj institutions-Some structural impediments and a training strategy in the year 2008 found that dominance of middle aged members and the proportion of proportion of younger members up to 30 years of age is higher. They also indicated that the increase in the proportion of younger members in successive election represents a healthy trend despite their relatively greater involvement in productive and reproductive activities and household work.

Table no 2. Education:

\begin{tabular}{|c|l|c|c|}
\hline Sl.No & Education & No. of Respondents & Percentage \\
\hline 1 & Illiterate & 10 & 3.0 \\
\hline 2 & Primary education & 125 & 37.9 \\
\hline 3 & High school & 129 & 39.1 \\
\hline 4 & Pre-university & 49 & 14.8 \\
\hline 5 & Graduation & 14 & 4.2 \\
\hline 6 & Diploma & 1 & 0.3 \\
\hline 7 & Post graduation & 2 & 0.6 \\
\hline & Total & $\mathbf{3 3 0}$ & $\mathbf{1 0 0}$ \\
\hline
\end{tabular}

Table number 2 depicts about the educational qualification of respondents. Out of 330 respondents separated it into 7 categories.10(30) respondents were illiterate, 125 (37.9\%) respondents were having primary education, $129(39.1 \%$ ) respondents were having high school education, $49(14.8 \%)$ respondents were having degree education, $2(0.6 \%)$ were completed their post-graduation and $1(0.3 \%)$ was completed her diploma education.

Here it shows that out of 330 respondents only 10(3.0\%) respondents were illiterates and $320(97 \%)$ respondents were having education. It is one of the good indications that educated respondents were in grass root level administration. Here it is better to know that more and more educated women entering into politics and local self government promotes development. Study report sponsored by government of India in the year 2008 on 'Empowerment of women through participation in Panchayati raj institutions-Some structural impediments and a 
training strategy in the year 2008 found that poor educational level among representatives exerts adverse influence on their performance and makes them vulnerable to exploitation

Table no 3. Regarding force to contest election.

\begin{tabular}{|c|l|c|c|}
\hline SI.No & Who forced & No. of respondents & Percentage \\
\hline 1 & Husband & 40 & 38.1 \\
\hline 2 & Brothers/sisters & 3 & 2.9 \\
\hline 3 & Family members & 0 & 0 \\
\hline 4 & Neighbours & 5 & 4.8 \\
\hline 5 & Relatives & 3 & 2.9 \\
\hline 6 & Political leaders & 54 & 51.4 \\
\hline 7 & Members of the caste & 0 & .0 \\
\hline 8 & Community leaders & 0 & .0 \\
\hline 9 & Religious leaders & 0 & .0 \\
\hline & Total & $\mathbf{1 0 5}$ & $\mathbf{1 0 0}$ \\
\hline
\end{tabular}

Here 105(31.8\%) respondents were forced to contest election. In Table Number 3, it shows that out of $105(31.8 \%)$ respondents were forced to contest election. 40(38.1\%) respondents opined that their husbands were forced to contest election. 54(51.4\%) respondents were said that political leaders were forced, 3 (2.9\%) respondents were forced by their brothers and sisters, 5(4.8\%) respondents forced by neighbors and relatives 3(2.9\%) respondents were forced by relatives.

In above table only those respondents who forced to contest election were 105(out of 330).In this analysis it is understood that out of 105 respondents $94(89.5 \%)$ respondents were forced from their husband and political leaders. Remaining 11 (10.5\%) respondents from their brothers and sisters, neighbors and relatives. The study shows that political parties were playing major role to decide candidates according to study. The reservation made obligation for rural women to contest in the Panchayat level election. Political parties were also no other option than giving importance to female members.

The study conducted in Rajashtan and Madhyapradesh (2008), Indicate that husbands, family members and relatives extended help to the women members in their election to panchayat.Caste and community members and political parties were ranked next in support. The help also received from local level officials and non-officials. Obviously traditional social institutions like family, caste and community continue to influence the functioning of political institutions.

Table no-4 Regarding financial problems to contest in the election:

\begin{tabular}{|c|l|c|c|}
\hline Sl.No & $\begin{array}{c}\text { Financial problems to } \\
\text { contest in the election }\end{array}$ & No. of respondents & Percentage \\
\hline 1 & Strongly agree & 30 & 9.1 \\
\hline 2 & Agree & 90 & 27.3 \\
\hline 3 & Disagree $\quad$ Total & 210 & 63.6 \\
\hline & $\mathbf{3 3 0}$ & $\mathbf{1 0 0}$ \\
\hline
\end{tabular}


In Table Number 4, it is observed that 30(9.1\%) respondents strongly agreed that they had financial problems to contest for the election, $90(27.3 \%)$ respondents agreed that they had problems of finance and remaining $210(63.6 \%)$ respondents were disagreed that they did not face financial problems to contest election.

Table no-5 Persons financed their election expenses:

\begin{tabular}{|c|l|c|c|}
\hline Sl.No & \multicolumn{1}{|c|}{$\begin{array}{c}\text { Person financed their election } \\
\text { expenses }\end{array}$} & No. of respondents & Percentage \\
\hline 1 & Husband & 166 & 50.3 \\
\hline 2 & Family members & 13 & 3.9 \\
\hline 3 & Political leaders & 92 & 27.9 \\
\hline 4 & Community leaders & 2 & .6 \\
\hline 5 & Children & 7 & 2.1 \\
\hline 6 & General public & 1 & .3 \\
\hline 7 & Self-Finance & 49 & 14.8 \\
\hline & $\quad$ Total & 330 & $\mathbf{1 0 0}$ \\
\hline
\end{tabular}

In Table Number 5, explained about persons financed respondents election expenses. 166( 50.3\%) respondents opined that their husband financed, 13 (3.9\%) respondents helped by family members, 92 ( $27.9 \%$ ) respondents opined that political leaders supported financially, $2(0.6 \%)$ respondents supported by community leader, 7 ( $2 \%$ ) were from their children, 1 ( 0.3\%) was from general public and 49( $14.8 \%)$ respondents were spent money from their own.

In above analysis, more than $50 \%$ of respondents were supported by their husband and more than $14 \%$ of respondents were spent their own amount. Remaining $27.9 \%$ respondents were supported by political parties. Interestingly 49(14.8\%) respondents were spent their own money and it shows that their interest and made attempt to take initiative in grass root democracy.

\section{Findings}

1. Greater part of respondents were belongs to 28 to 47 years of age group (255).

2. Best part of respondents were completed their primary and high school education (254)

3. Only 10 respondents were belonging to illiterate group.

4. Bulk of respondents disagreed about force to contest election (205).

5. Out of 105 respondents who said that they were forced to contest election. 54 respondents forced by political leaders and 40 respondents were enforced by their husband.

6. Majority of respondents disagreed about financial problem to contest in election.

7. 166 respondents financially supported by their husband, 92 respondents by political leaders and 49 respondents were self financed.

\section{Conclusions}

Some women are having manifold roles. For example she is an employee, Panchayat member and a house wife. They find it very hectic to balance all these responsibilities. But they are also competent enough in Panchayat activities. In this type of situation, there is a need of sensitizing male members in Gram Panchayat and also at home. 
Women Panchayat members more proficient to demand for adequate supply of drinking water, housing community development programme and any other social welfare programme. The need of giving responsibility in such communities will enable efficient local self-governance.

One of the interesting issues is more number of educated respondents and youngsters were contesting for the election. If educated and youngsters really take responsibility and initiative in grassroots administration it will benefit rural areas for better administration. It is remarkable that in this study only 10 respondents belong to illiterate category and all the 320 respondents are educated. Majority were forced by their husband and political leaders to contest in the election. It raises doubt that really they are enjoying power or for the others sake they are in power. Even if it is reservation or may be self interest the participation of women members in Panchayat Raj Institutions making a tremendous change in grass root democracy. It is also need of the day. Women are also having knowledge of basic necessity of communities. Such as drinking water, street light, housing, roads and also many other need based issues.

\section{References}

[1] Chakraborthy U (2010), From Gram Swaraj to Gram Sabha, Five decade in search of an institution, Kurukshetra P.P 8-13.

[2] Hazra A (2010), Panchayati Raj system: Strengthening rural decentralization and democracy. Kurukshetra P.P 1922.

[3] K.S Narayana (2010). Panchayati Raj and rural development- Retrospection of ancient system of village Panchayats and present four of Panchayat raj institutions, Kurukshetra PP27-29.

[4] P. Malyadri (2010), Empowerment of rural women through Panchayati raj institutions .Kuruksehtra PP 49-51.

[5] Parwar.M ( 2010), Role of SHG's in strengthens grass root democracy. Experiences of Haryana, Kuruksehtra , P.P 52-54.

[6] Gayathri .O ( 2015), Women and Political internet, women's link vol.21.No.3.PP 26-32.

[7] Lal D, Ojha A and Sabharwal NS (2014), Women's political representation in the $16^{\text {th }}$ Lok Sabha continuity contestation or change women's link Vol.20, No.3, and P.P 3-10.

[8] Laha .M (2014), Representation in participation of women in Panchayati Raj Institutions, Women's link. Vol.20.No.3 PP 11-15.

[9] Singh R (2014), Panchayati Raj and women empowerment in Bundelkhand, women's link, Vol 20. No.3 PP.1622.

[10] Chterjee A(2014) Participation of rural women in local politics, women's link .vol20. No.3 .PP 36-38.

[11] Dahlerup D and Routledge 2017, Women quota and politics. PP 312. Women's link P.P 39-40.

[12] Sinha Archana (2017), Women and Sustainable development, Women's link Vol.23.No.1.P.P.7-11.

[13] Priya L ( 2017) Political participation of women in Suriya, Women's link Vol.23. No.1.P.P.12-16.

[14] Mathew .L (2002), Gender inequality - Reexamined. Integral Liberation Vol.6. No.4 PP 248 to 250.

[15] Singh k Ajay (2002), Women's empowerment -promises and reality, Integral liberation Vol 6. No.4, P.P 251-256. 